6. Архипова А.А. ОПЫТ СТРОИТЕЛЬСТВА ЗДАНИЙ ДЛЯ ДОСУГА МОЛОДЕЖИ. Жилищное строительство. 2018. № 11. С. 22-28.

7. Архипова А.А. 1.2. СПЕЦИФИКА ЭСТЕТИЗАЦИИ ОБРАЗОВАТЕЛЬНОЙ СРЕДЫ. В КНИГе: Инновационные технологии российского и зарубежного образования Нагорнова А.Ю., Файн Т.А., Архипова А.А., Гаврилова Ю.А., и др. Коллективная монография. Ответственный редактор А.Ю. Нагорнова. Ульяновск, 2018. С. 19-28.

8. Бабич М.А.; Борисова Н.А. и др. Инклюзивное образование в ВУЗе: комплект учебнометодических материалов программы курсов повышения квалификации сотрудников образовательных организаций высшего образования, расположенных на территории СевероЗападного федерального округа / Сост. О.Л. Леханова; под ред. О.А. Денисовой. Череповец: Череповецкий государственный университет, 2017. 259 с. ISBN 978-5-85341-777-9

9. Калинина И.Ф., Ткаченко А.В. Занятия физической культурой как условие и фактор укрепления здоровья студенческой моло-дежи. Педагогический журнал. 2017. Т. 7. № 2А. С. 443-448.

10. Кетриш Е. В. Теория и практика инклюзивного образования (на примере физического воспитания) [Электронный ресурс]: учебное пособие / Е. В. Кетриш, Т. В. Андрюхина, Н. В. Третьякова; под общ. ред. Е. В. Кетриш. Екатеринбург: Изд-во Рос. гос. проф.-пед. ун-та, 2017. 127 с. Режим доступа: http://elar.rsvpu.ru/handle/123456789/21891. ISBN 978-5-8050-0622-8

11. Китикарь О.В. Формирование готовности будущих педагогов по физической культуре к инклюзивному образованию в процессе физического воспитания. Сборник материалов третьей международной научной конференции.2016.С.73-78.

12. Огольцова Е. Г., Тимохина А. Э., Сергеева Е. А. Развитие ин-клюзивного образования в России // Молодой ученый. - 2017. - №50. - С. 249-252.

13. Радченко А.С., Лубышева Л.И., Соколова И.В. Физическая культура и здоровье молодежи в фокусе научно-практической конференции. Физическая культура: воспитание, образование, тренировка. 2018. № 3. С. 42.

14. Самохин И. С. Содержание основных понятий инклюзивного образования / И. С. Самохин, Н. Л. Соколова, М. Г. Сергеева // Научный диалог. - 2016. - № 9 (57). - С. 311-327.

15. Тармаев А.А., Тармаева И.Ю. Проблемы реализации требо-ваний к инклюзивному образованию в образовательных ор-ганизациях высшего образования. В сборнике: Современные проблемы профессионального образования: опыт и пути реше-ния. Материалы Второй всероссийской научно-практической конференции с международным участием. 2017. С. 465-469.

\title{
Баклушина И.В.
}

Об интеграции ВІМ-технологий в образовательный процесс технического вуза ФГБОУ ВО «Сибирский государственный индустриальный университет» (Россия, Новокузнецк)

doi: $10.18411 / \mathrm{j}-02-2020-135$

idsp: ljournal-02-2020-135

\section{Аннотация}

Описана реализация интеграции ВIM-технологий в образовательный процесс технического вуза по направлению подготовки 08.03.01 - «Строительство» на опыте Сибирского государственного индустриального университета, г. Новокузнецк.

Ключевые слова: ВIM-технологии, технология информационного моделирования зданий

\section{Abstract}

The paper describes the implementation of the integration of BIM - technology into the educational process of a technical university in the field of preparation 08.03.01 "Construction" based on the experience of the Siberian State Industrial University, Novokuznetsk.

Keywords: BIM - technologies, building information modeling technology

Согласно положений федерального закона от 27.06.2019 N 151-Ф3 "О внесении изменений в Федеральный закон "Об участии в долевом строительстве многоквартирных домов и иных объектов недвижимости и о внесении изменений в 
некоторые законодательные акты Российской Федерации" и отдельные законодательные акты Российской Федерации" информационная модель объекта капитального строительства представляет собой базу данных об объекте капительного строительства, включающую в себя подготовленные в электронной форме сведения, документы, материалы о таком объекте, формируемые при проведении инженерных изысканий, подготовке обоснования инвестиций, проектировании, строительстве, эксплуатации, реконструкции, капительном ремонте и выводе из эксплуатации объекта капитального строительства. Изменения направлены на более полную регламентацию процессов нормирования всех «жизненных циклов» объектов капитального строительства, создание дополнительных информационных ресурсов, обеспечивающих полную информацию об объекте, позволяющих минимизировать неоправданные риски при принятии управленческих решений. Внедрение технологий информационного моделирования в строительство входит в число приоритетных задач национального проекта «Жилье и городская среда», разработанный во исполнение Указа Президента Российской Федерации от 7 мая 2018 года № 204 «О национальных целях и стратегических задачах развития Российской Федерации на период до 2024 года».

Технология информационного моделирования зданий (Building Information Modelling - BIM) ориентирована на создание единой научной, технологической, технической, нормативно-организационной, информационной среды для интеллектуального управления жизненным циклом объектов строительства с целью качественного повышения эффективности планирования и надежности реализации инфраструктурных проектов всех уровней. Инновационная деятельность проектирующих, строительных и эксплуатирующих организаций, основанная на BIMтехнологии, должна способствовать созданию благоприятных условий, обеспечивающих сокращение сроков проектирования и сдачи в эксплуатацию объектов строительства, а также уменьшению затрат при их эксплуатации. Создаваемая в процессе проектирования информационная модель здания или сооружения (BIMмодель) содержит полный спектр информации о нем: от объемно-планировочных решений до оборудования

Эффективность внедрения ВІМ-технологий в процесс проектирования и строительства демонстрирует динамика роста эффективности ВIM для начинающих компаний и компаний, уже закрепившихся на строительном рынке [1].

В настоящее время программы, которые предназначены для проектирования внутренних инженерных систем и обеспечения комплексного решения, основанного на концепции информационного моделирования здания для проектировщиков, подрядчиков и инженеров, сочетают в себе мощные возможности проектирования и расчета инженерных систем, и в несколько раз увеличивают эффективность работы [2]. Например, в программном комплексе Autodesk Revit, активно применяющимся для ВIM-моделирования, имеются встроенные комплексы, позволяющие выполнять расчеты инженерных систем, а также проводить анализ энергопотребления зданий, что позволяет обеспечивать высокую энергоэффективность объектов строительства.

Несомненно, ВІМ-технологии требуют значительных затрат на стадии внедрения в проектные, строительные и эксплуатирующие организации. В большей степени сложности внедрения связаны с кадровым обеспечением специалистами по ВIM-технологиям, обладающими соответствующими профессиональными компетенциями. Содержательной и организационной основой профессионального образования являются федеральные государственные образовательные стандарты (ФГОСы) по направлению подготовки Строительство. В частности ФГОС по направлению подготовки 08.03.01 Строительство (уровень бакалавриат), утвержденный приказом Минобрнауки РФ № 481 от 31.05.2017г., определяет результаты освоения программы бакалавриата, в соответствии с которыми совокупный ожидаемый 
результат образования по завершении освоения основной образовательной программы бакалавриата определяется приобретаемыми выпускником компетенциями, т.е. его способностями применять знания, умения, навыки и личные качества в соответствии с задачами профессиональной деятельности.

В Сибирском государственном индустриальном университете (г. Новокузнецк) в 2019 году была разработана основная образовательная программа (ООП) по направлению подготовки 08.03.01 Строительство в полном соответствии с ФГОС [3], способная обеспечить формирование способности выпускника применять знания, умения, навыки и личные качества в соответствии с задачами, связанными с применением BIM-технологий в рамках некоторых общепрофессиональных и профессиональных компетенций, в отличие от ООП, соответствующей предыдущему ФГОС[4]. Основная образовательная программа предполагает реализацию двух направленностей (профилей): направленность (профиль) № 1 «Инженерные системы жизнеобеспечения в строительстве»; направленность (профиль) № 2 «Промышленное и гражданское строительство». Основная образовательная программа (ООП) по направлению подготовки 08.03.01 Строительство в соответствии с ФГОС формирует профессиональные компетенции в соответствии с профессиональными стандартами.

В соответствии с требованиями ФГОС в результате освоения ООП бакалавриата у выпускника должны быть сформированы универсальные, общепрофессиональные и профессиональные компетенции. Общепрофессиональные компетенции выпускников и индикаторы их достижения, обеспечивающие формирование способности выпускника применять знания, умения, навыки и личные качества в соответствии с задачами, связанными с применением ВIM-технологий приведены в таблице 1.

Таблица 1.

Общепрофессиональные компетенщии выпускников и индикаторы их достижения, обеспечивающие формирование способности выпускника применять знания, умения, навыки и личные качества в соответствии с задачами, связанными с применением ВІМ-технологий

\begin{tabular}{|c|c|c|}
\hline $\begin{array}{l}\text { Наименовани } \\
\text { е категории } \\
\text { (группы) } \\
\text { ОПК }\end{array}$ & Код и наименование ОПК & Код и наименование индикатора достижения ОПК \\
\hline $\begin{array}{l}\text { Информацион } \\
\text { ная культура }\end{array}$ & $\begin{array}{l}\text { ОПК-2. Способен вести } \\
\text { обработку, анализ и } \\
\text { представление информации в } \\
\text { профессиональной } \\
\text { деятельности с } \\
\text { использованием } \\
\text { информационных и } \\
\text { компьютерных технологий }\end{array}$ & $\begin{array}{l}\text { ОПК-2.2 Обрабатывает и хранит информацию в } \\
\text { профессиональной деятельности с помощью баз } \\
\text { данных и компьютерных сетевых технологий. } \\
\text { ОПК-2.3 Представляет информацию с помощью } \\
\text { информационных и компьютерных технологий. } \\
\text { ОПК-2.4 Применяет прикладное программное } \\
\text { обеспечение для разработки и оформления } \\
\text { технической документации. }\end{array}$ \\
\hline $\begin{array}{l}\text { Проектирован } \\
\text { ие Расчетное } \\
\text { обоснование }\end{array}$ & $\begin{array}{l}\text { ОПК-6. Способен участвовать } \\
\text { в проектировании объектов } \\
\text { строительства и жилищно- } \\
\text { коммунального хозяйства, в } \\
\text { подготовке расчетного и } \\
\text { технико-экономического } \\
\text { обоснований их проектов, } \\
\text { участвовать в подготовке } \\
\text { проектной документации, в } \\
\text { том числе с использованием } \\
\text { средств автоматизированного } \\
\text { проектирования и } \\
\text { вычислительных } \\
\text { программных комплексов }\end{array}$ & $\begin{array}{l}\text { ОПК-6.3 Выполняет графическую часть проектной } \\
\text { документации здания (сооружения), систем } \\
\text { жизнеобеспечения, в том числе с использованием } \\
\text { средств автоматизированного проектирования. }\end{array}$ \\
\hline
\end{tabular}


На основе профессиональных стандартов и обобщения зарубежного и отечественного опыта были сформированы профессиональные компетенции с учетом мнения работодателей.

Дисциплины учебного плана, формирующие индикаторы достижения компетенций, обеспечивающие формирование способности выпускника применять знания, умения, навыки и личные качества в соответствии с задачами, связанными с применением ВIM-технологий используют ряд задач в области профессиональной деятельности с постепенным переходом от воспроизводящих и реконструктивновариативных к эвристическим. Это обеспечит формирование первичных навыков проектных действий при реализации дисциплины «Компьютерное проектирование в строительстве» с переходом к базовым навыкам работы с BIM-моделями в проектной практике.

Предполагается, что реализация дисциплин учебного плана, отвечающих за формирование вышеприведённых индикаторов компетенций, позволит сформировать у обучающихся практические навыки создания и применения ВIM-моделей в рамках проектных типов задач профессиональной деятельности. Большая часть индикаторов формируется в самостоятельной работе, что, при правильной ее организации и контроле [5], позволит управлять учебной деятельностью [6] и позволит сформировать компетентностную ориентацию обучающихся [7, 8] в области применения ВIMтехнологий, что, наряду с реализацией возможной траектории получения обучающимися профессии рабочего при освоении основной образовательной программы высшего образования [9] будет способствовать их социальной мобильности, конкурентоспособности, устойчивости на рынке труда и адаптации к качественным изменениям социально-экономического пространства региона.

$$
* * *
$$

1. Буравлева, А.Ф. Внедрение ВІМ-технологий в процесс проектирования и строительства объектов недвижимости / А.Ф Буравлева., Н.А. Клипина, М.О. Крутилова // Вестник научных конференций - 2016. - № 10-3 (14). - С. 36-39.

2. Гнедых, В.С. Интеграция программных комплексов информационного моделирования зданий в области отопления и вентиляции / В.С. Гнедых, Д.А. Дёмшина // ВІМ-моделирование в задачах строительства и архитектуры. Материалы II Международной научно-практической конференции. - СПб., 2019. - С. 257-261.

3. Федеральный государственный образовательный стандарт высшего образо-вания - бакалавриат по направлению подготовки 08.03.01 «Строитель-ство», утвержденный приказом Министерства образования и науки Российской Федерации от «31» мая 2017 г. № 481.

4. Баклушина И.В., Зоря И.В. Об опыте создания учебного плана для бакалавров направления 08.03.01 Строительство в Сибирском государственном индустриальном университете, г. Новокузнецк // Вестник науки и образования Северо-Запада России, 2015. T. 1, № 1. URL: http://vestnik-nauki.ru/wpcontent/uploads/2015/10/2015№1-Баклушина.pdf (Дата обращения 08.09.2016 г.)

5. Баклушина, И.В. Организация и контроль самостоятельной работы студен-тов/И.В. Баклушина, М.Н. Башкова//Вестник СибГИУ, 2014. - №4. - С. $62-65$.

6. Баклушина, И.В. Контроль самостоятельной работы как управление учебной деятельностью студентов/И.В.Баклушина и др.//Вестник СибГИУ. - 2015. - №1. - С. 95-97.

7. Баклушина И.В., Михальцова Л.Ф. О компетентностной ориентации студентов в условиях образовательного процесса технического вуза (из опыта реализации дисциплины «Теплоснабжение»)//Вестник науки и образования Северо-Запада России. 2016. Том. 2. № 2. . Режим досту-па http://vestnik-nauki.ru/wp-content/uploads/2016/04/2016-N2-Baklushina.pdf (Дата обращения 19.07.2019 г.)

8. Баклушина И.В. О компетентностной ориентации обучающихся в условиях образовательного процесса технического вуза // EUROPEAN SOCIAL SCI-ENCE JOURNAL. 2018. № 5-1. - C. 197202.

9. Баклушина И.В., Башкова М.Н. О реализации возможной траектории полу-чения обучающимися профессии рабочего при освоении основной образовательной программы высшего образования//Вестник Сибирского государственного индустриального университета, 2016. - № 2. - C. $76-79$. 